\title{
Sulfur Limits of Detection and Spectral Interference Corrections for DWPF Sludge Matrices by Inductively Coupled Plasma Emission Spectrometry (U)
}

February 20, 2004

Savannah River Technology Center Measurement Technology Department Analytical Development Section 
This document was prepared in conjunction with work accomplished under Contract No. DE-AC09-96SR18500 with the U. S. Department of Energy.

\section{DISCLAIMER}

This report was prepared as an account of work sponsored by an agency of the United States Government. Neither the United States Government nor any agency thereof, nor any of their employees, makes any warranty, express or implied, or assumes any legal liability or responsibility for the accuracy, completeness, or usefulness of any information, apparatus, product or process disclosed, or represents that its use would not infringe privately owned rights. Reference herein to any specific commercial product, process or service by trade name, trademark, manufacturer, or otherwise does not necessarily constitute or imply its endorsement, recommendation, or favoring by the United States Government or any agency thereof. The views and opinions of authors expressed herein do not necessarily state or reflect those of the United States Government or any agency thereof.

This report has been reproduced directly from the best available copy.

Available for sale to the public, in paper, from: U.S. Department of Commerce, National Technical Information Service, 5285 Port Royal Road, Springfield, VA 22161, phone: (800) 553-6847, fax: (703) 605-6900

email: orders@ntis.fedworld.gov

online ordering: http://www.ntis.gov/help/index.asp

Available electronically at http://www.osti.gov/bridge

Available for a processing fee to U.S. Department of Energy and its contractors, in paper, from: U.S. Department of Energy, Office of Scientific and Technical Information, P.O. Box 62, Oak Ridge, TN 37831-0062,

phone: (865)576-8401,

fax: (865)576-5728

email: $\underline{\text { reports@ adonis.osti.gov }}$ 
Keywords:

Sulfur

LOD

Interference

ICP-ES

Sludge

Retention:

Permanent

\title{
Sulfur Limits of Detection and Spectral Interference Corrections for DWPF Sludge Matrices by Inductively Coupled Plasma Emission Spectrometry
}

\author{
A. R. Jurgensen \\ J. C. Hart \\ L. L. Farrow
}

February 20, 2004

Westinghouse Savannah River Company

Savannah River Site

Aiken, SC 29808 
This page was intentionally left blank 


\section{TABLE OF CONTENTS}

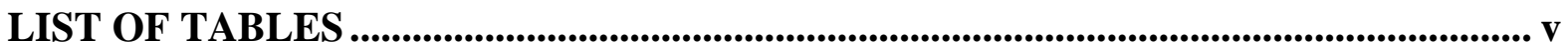

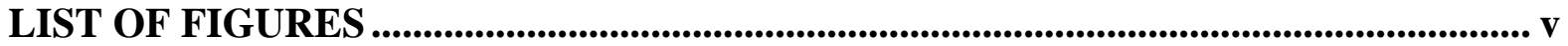

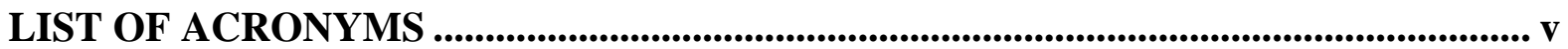

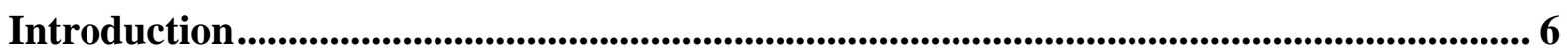

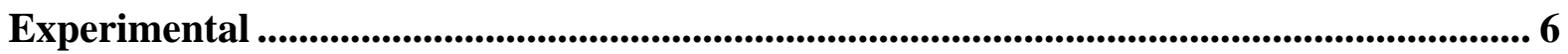

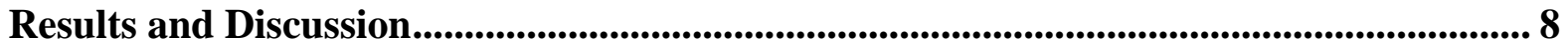

\section{LIST OF TABLES}

Table 1. Sulfur Limits of Detection in a 2\% $\mathrm{HNO}_{3}$ Matrix. ......................................... 8

Table 2. Typical Equivalent $\mathrm{S}(\mu \mathrm{g} / \mathrm{ml})$ in $2 \% \mathrm{HNO}_{3}$ Matrix.........................................9 9

Table 3. Digested Radioactive Sludge Sulfur Concentrations $(\mu \mathrm{g} / \mathrm{ml})$.......................... 11

Table 4. Sludge Batch 2 Sulfur Concentrations $(\mu \mathrm{g} / \mathrm{mL})$ for both ICP-ES Emission

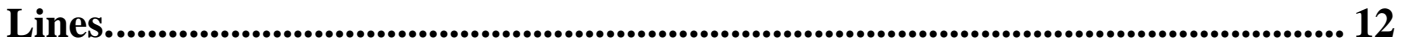

Table 5. Sludge Batch 3 Sulfur Concentrations $(\mu \mathrm{g} / \mathrm{mL})$ for both ICP-ES Emission

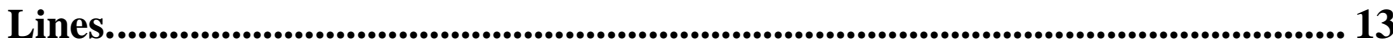

\section{LIST OF FIGURES}

Figure 1. Iron spectral interference on sulfur concentration

\section{LIST OF ACRONYMS}

$\begin{array}{ll}\text { ADS } & \text { Analytical Development Section } \\ \text { DWPF } & \text { Defense Waste Processing Facility } \\ \text { IUPAC } & \text { International Union of Pure and Applied Chemistry } \\ \text { LOD } & \text { Limit of Detection } \\ \text { NIST } & \text { National Institute of Science and Technology } \\ \text { S } & \text { Sulfur } \\ \text { SRTC } & \text { Savannah River Technology Center } \\ \text { WSRC } & \text { Westinghouse Savannah River Company }\end{array}$


WSRC-TR-2004-00090, Rev. 0

\section{$\underline{\text { Introduction }}$}

The Analytical Development Section (ADS) of the Savannah River Technology Center (SRTC) has been requested to perform sulfur (S) analysis on digested Defense Waste Processing Facility (DWPF) radioactive sludge and supernatant samples by Inductively Coupled Plasma Emission Spectrometry (ICP-ES). The amount of sulfur is a concern because there are sulfur limits for the incoming feed to DWPF, due to glass melter, process vessel, and off-gas line corrosion concerns and limited sulfur solubility in the glass wasteform. Recent changes in the Tank Farm washing strategy and H-Canyon stream additions change the amount of sulfur in the sludge. Increasing the sulfur concentration in the sludge challenges the current limits, so accurately determining the amount of sulfur present in a sludge batch is paramount.

There are two important figures of merit that need to be evaluated for this analysis. The first is the detection limit (LOD), the smallest concentration of an element that can be detected with a defined certainty. This issue is important since the sulfur concentration in these process streams is low. Another critical analytical parameter is the effect on the $S$ quantitation from potential spectral interferences. Spectral interferences are caused by background emission from plasma recombination events, scattered and stray light from the line emission of high concentration elements, or molecular band emission and from direct or tailing spectral line overlap from a matrix element. Any existing spectral overlaps could give false positives or increase the measured $S$ concentrations in these matrices. The purpose of this study was to document the Analytical Development Sections's contained ICP-ES performance in these two areas.

\section{Experimental}

The instrument used for these measurements is a Horiba Jobin Yvon Model 170C Inductively Coupled Plasma Atomic Emission Spectrometer (ICP-ES) with a $1.5 \mathrm{~kW}, 40 \mathrm{MHz}$ solid-state generator and torch box assembly contained in a radiological fume hood ${ }^{1}$. The spectrometer section of the instrument consists of a 1-meter Czerny-Turner monochromator with a 1-m focal length, $80 \times 110 \mathrm{~mm}$, and 2400 grooves/mm grating with 5 pm resolution ( $2^{\text {nd }}$ order full width half max) at $182 \mathrm{~nm}$ and a 0.5-meter polychromator. The polychromator uses a Paschen-Rungen (Rowland Circle) design with a 0.5-m focal length (3000 grooves $/ \mathrm{mm}$ ) grating in first order and with a flat-field segment to detect $\mathrm{Na}, \mathrm{Li}$ and $\mathrm{K}$. All measurements were made in the Gaussian peak mode, with nine points sampled across the $\mathrm{S}$ emission line peak shape. Although lower LODs could be acquired in the single or "median" (5 points) modes, the Gaussian mode provides higher precision data, since more points on the emission profile are measured. In addition, there is acceleration in the calibration curve drift in the single or "median” modes. All data were acquired following procedure ADS-1564, "Contained ICP-ES for Radioactive Sample Analysis, JY170C”2. A $5 \mu \mathrm{g} / \mathrm{mL}$ chromium (Cr) instrument profile standard was measured daily to properly align the polychromator entrance

\footnotetext{
${ }^{1}$ F. M. Pennebaker and J.C. Hart, WSRC-TR-2003-00063, “Final Report on Jobin Yvon Contained Inductively Coupled Plasma Emission Spectrometer (ICP-ES)”, Westinghouse Savannah River Site 2/6/03.

2 L16.1-ADS-1564, “Contained ICP-ES for Radioactive Sample Analysis, JY170C”, Westinghouse Savannah River Site, 9/01/03
} 
slit with the plasma analytical zone. Carbon emission from excited air was used to align the monochromator entrance slit. The three main sulfur optical emission wavelengths are $180.676,181.974$, and $182.568 \mathrm{~nm}$. Only the last two lines were studied due to time constraints at the initiation of this investigation. The 182.568 line was rejected after a preliminary survey, primarily because it is not very sensitive and suffers severe spectral interferences from matrix elements in a digested surrogate waste glass. For this report, sulfur measurements were made at the $181.97 \mathrm{~nm}$ wavelength both sequentially on the monochromator and on the simultaneous polychromator channel with no background correction points. Continuous background emission (either flat or sloping) across the sulfur peak may be removed by subtracting the off-peak background intensity or an intensity linearly interpolated between two selected wavelengths on either side of the line emission. This protocol will not correct for the direct line overlaps on sulfur that are present during the analysis of complex sludge and glass digestates. And since additional measurements must be made to perform background correction, both the analysis time and expended sample volume increase. A $2 \mu \mathrm{g} / \mathrm{mL}$ scandium (Sc) in $2 \% \mathrm{HNO}_{3}$ internal standard was added to all solutions to compensate for minor fluctuations in the plasma and sample introduction system. Scandium intensity was measured simultaneous to sulfur using a fixed channel on the polychromator.

Limits of Detection have been determined utilizing the International Union of Pure and Applied Chemistry (IUPAC) ${ }^{3}$ methodology as follows:

$$
\begin{gathered}
\mathbf{X}_{\mathrm{L}}=\bar{X}_{\mathrm{bl}}+\mathbf{k s}_{\mathrm{bl}} \\
\mathrm{C}_{\mathrm{L}}=\left(\mathrm{X}_{\mathrm{L}}-\bar{X}_{\mathrm{bl}}\right) / \mathrm{S}
\end{gathered}
$$

where

$\mathrm{X}_{\mathrm{L}}$ : Smallest measure detected with reasonable certainty

$\bar{X}_{\text {bl: }}$ Mean of blank measures

k: Uncertainty factor

$\mathrm{s}_{\mathrm{bl}}$ : $\quad$ Standard deviation of blank measures

$\mathrm{C}_{\mathrm{L}}$ : $\quad$ Limit of Detection

S: $\quad$ Sensitivity (Slope of the Calibration Curve)

Note: "A value of 3 for $\mathrm{k}$. . . is strongly recommended; for this value, a 99.6\% confidence level applies only for a strictly one sided Gaussian distribution. At low concentrations, non-Gaussian distributions are more likely. Moreover, the values of $\bar{X}_{\text {bl }}$ and $\mathrm{S}_{\mathrm{bl}}$ are themselves only estimates based on limited measurements. Therefore, in a practical sense, the $3 \mathrm{~S}_{\mathrm{bl}}$ value usually corresponds to a confidence level of about $90 \%$." 3 ADS has chosen to use $\mathrm{k}=5$ to increase the confidence interval above $90 \%$.

For the LOD determination twenty replicate blank measurements of the $2 \%$ nitric acid solution were collected. The number of replicate blank measurements is not specified by

\footnotetext{
${ }^{3}$ IUPAC Compendium of Analytical Nomenclature, Definitive Rules, $3^{\text {rd }}$ Edition, Section 10.3.3.3.1 "Limit of Detection" (1997).
} 
IUPAC for the LOD determination, but literature references recommend twenty ${ }^{4,5}$. The S sensitivity (slope of the calibration curve) was calculated from the intensities of the $2 \%$ $\mathrm{HNO}_{3}$ blank, $5 \mu \mathrm{g} / \mathrm{mL}$ and $10 \mu \mathrm{g} / \mathrm{mL}$ sulfur standard solutions. To better quantify $\mathrm{S}$ at low concentrations, the calibration curve was forced through the origin and the blank intensity was subtracted from the sample value. Standards were made from a $1000 \mu \mathrm{g} / \mathrm{mL}$ NIST traceable stock solution diluted in the $2 \% \mathrm{HNO}_{3}$ matrix blank.

For the spectral interference study, several single element standards at the nominal DWPF sludge concentrations were analyzed on both $\mathrm{S}$ lines to determine the equivalent $\mathrm{S}$ detected in $\mu \mathrm{g} / \mathrm{mL}$ in $2 \% \mathrm{HNO}_{3}$. As for the LOD study, all the standards were diluted from a 1000 $\mu \mathrm{g} / \mathrm{mL}$ NIST traceable stock solution and spiked with $2 \mu \mathrm{g} / \mathrm{mL}$ Sc added as an internal standard. To eliminate carry-over, a $2 \% \mathrm{HNO}_{3}$ solution was flushed through the system between interferent solutions until the background intensity was reduced to the blank level.

\section{Results and Discussion}

The sulfur detection limit results for both emission lines explored are listed in Tables 1 . The LOD for the monochromator line is $5 x$ better than the polychromator line even though their atomic transition (wavelength) is the same. Although the 1-meter monochromator will have better stray and scattered light rejection, the difference in sensitivity (intensity per unit concentration) between the two spectrometers is surprising. The polychromator photomultiplier tube may be defective or improperly adjusted. If sulfur is present, the monochromator is the spectrometer of choice for low-level sulfur analysis.

Table 1. Sulfur Limits of Detection in a $2 \% \mathrm{HNO}_{3}$ Matrix.

\begin{tabular}{rcc}
\hline \hline & $\begin{array}{c}\text { Polychromator } \\
\mathbf{1 8 1 . 9 7 4} \mathbf{~ n m}\end{array}$ & $\begin{array}{c}\text { Monochromator } \\
\mathbf{1 8 1 . 9 7 8} \mathbf{~ m m}\end{array}$ \\
\hline \hline Blank Avg. (20) & 0.00728 & 0.0127 \\
Blank Stdev. (20) & 0.00046 & 0.00037 \\
S (Intensity/ $\mu \mathbf{g} / \mathbf{m L}))$ & 0.018386 & 0.07102 \\
& & \\
IUPAC 3 $\sigma$ LOD $(\mu \mathbf{g} / \mathbf{m L})$ & 0.07 & 0.016 \\
IUPAC 5 $\sigma$ LOD $(\mu \mathbf{g} / \mathbf{m L})$ & $\mathbf{0 . 1 3}$ & $\mathbf{0 . 0 2 6}$ \\
\hline \hline
\end{tabular}

Typical spectral interferences on both $\mathrm{S}$ emission lines in $\mu \mathrm{g} / \mathrm{mL}$ in $2 \% \mathrm{HNO}_{3}$, are listed in Table 2 for the major DWPF sludge elements. These listed ratios should be re-determined periodically since plasma and sample introduction conditions, and spectrometer alignment vary over time. The interferences are considerably lower for the monochromator line than the polychromator fixed channel and only significant for $\mathrm{Mn}, \mathrm{Al}$, and $\mathrm{U}$. In contrast, the interferences on the polychromator channel are severe, especially for Fe, Mn, U, and Al with factors as much as $15 x$ higher. Interelement overlaps may vary for the same emission line among spectrometers due to differences in resolution, as determined by spectrometer focal

\footnotetext{
${ }^{4}$ P. W. J. M Boumans, Inductively Coupled Plasma Emission Spectroscopy, Part 1, Methodology, Instrumentation, and Performance, (John Wiley \& Sons, New York ,1987), p 106.

${ }^{5} \mathrm{~J}$. D. Winefordner, Trace Analysis, Spectroscopic Methods for Elements, (John Wiley \& Sons, New York, 1976), p 5.
} 
WSRC-TR-2004-00090, Rev. 0

length, grating line density, the entrance and exit slit widths, and by line dispersion. By using the JY170C monochomator, sulfur spectral interference corrections are minimized.

Table 2. Typical Equivalent $\mathrm{S}(\mu \mathrm{g} / \mathrm{ml})$ in $2 \% \mathbf{H N O}_{3}$ Matrix

\begin{tabular}{|c|c|c|}
\hline Interferent & $\begin{array}{c}\text { Polychromator } \\
181.974\end{array}$ & $\begin{array}{c}\text { Monochromator } \\
181.978\end{array}$ \\
\hline Al - $200 \mu \mathrm{g} / \mathrm{ml}$ & 0.249 & 0.055 \\
\hline Ca - $100 \mu \mathrm{g} / \mathrm{ml}$ & 0.103 & $0.007 *$ \\
\hline $\mathrm{Fe}-400 \mu \mathrm{g} / \mathrm{ml}$ & 1.45 & $0.016^{*}$ \\
\hline Mg- $100 \mu \mathrm{g} / \mathrm{ml}$ & $0.064^{*}$ & $0.015^{*}$ \\
\hline $\mathrm{Mn}-100 \mu \mathrm{g} / \mathrm{ml}$ & 1.93 & 0.146 \\
\hline $\mathrm{Na}-400 \mu \mathrm{g} / \mathrm{ml}$ & $0.042 *$ & $0.011^{*}$ \\
\hline $\mathrm{Ni}-100 \mu \mathrm{g} / \mathrm{ml}$ & $0.043^{*}$ & $0.012 *$ \\
\hline$P$ - $100 \mu \mathrm{g} / \mathrm{ml}$ & $0.001^{*}$ & $0.002 *$ \\
\hline $\mathrm{Si}-100 \mu \mathrm{g} / \mathrm{ml}$ & $0.084^{*}$ & $0.002 *$ \\
\hline $\mathrm{Sr}-100 \mu \mathrm{g} / \mathrm{ml}$ & $0.083^{*}$ & $0.008^{*}$ \\
\hline $\mathrm{U}-200 \mu \mathrm{g} / \mathrm{ml}$ & 0.308 & 0.068 \\
\hline
\end{tabular}

* Values below the sulfur LOD.

Quadruplicate samples of dried DWPF radioactive sludge, both Sludge Batchs 2 \& 3, were digested for 2 hrs at $100^{\circ} \mathrm{C}$ in aqua regia $\left(3: 1 \mathrm{HCl} / \mathrm{HNO}_{3}\right)$ in sealed Teflon vessels. These acid digestates were analyzed on both emission lines with results summary listed in Table 3. Complete detailed spectral interference corrections for all major elements in these sludge samples, plus blanks and controls are listed in Tables 4 and 5 . These results were not corrected for dilutions performed in the SRTC High-Activity Cells. Correction factors were determined from single element standards on the day each of the two batches of samples were analyzed. After correction ratios are applied, sulfur concentrations converge with an average difference of only $13 \%$. Considering the propagated errors associated with this number, the difference between the two is small. This variation reduces to only $10 \%$, if sample AR-1-T40-Qual-3 is removed from the average. The average polychromator sulfur correction was $81 \%$ while the monochromator's adjustment was only $4.8 \%$ (a $15 \mathrm{x}$ difference). Clearly the monochromator analytical results would be more accurate and the spectrometer of choice for this measurement. The final official results (on a wt\% dried sludge basis) for Sludge Batches $2 \& 3$ and additional information on sulfur analysis of DWPF feed streams can be found in Bibler and $\mathrm{Hay}^{6}$. Finally, equivalent sulfur concentrations for a series of 50 to $900 \mu \mathrm{g} / \mathrm{mL}$ Fe standards were determined to prove that the correction factors on the sulfur lines are linear with increasing interferent. The linear relationship is presented in Figure 1. This relationship should be similar for all the other interfering elements. It would not be necessary to measurement correction ratios at more than one concentration.

\footnotetext{
${ }^{6}$ N. E. Bibler and M. S. Hay, WSRC-TR-2004-00092, "Total and Soluble Sulfur in a Sample from Tank 40 (Sludge Batch 2) and a Composite of Samples from Tank 51 (Sludge Batch 3)”, Westinghouse Savannah River Site, 2/20/04
} 
WSRC-TR-2004-00090, Rev. 0

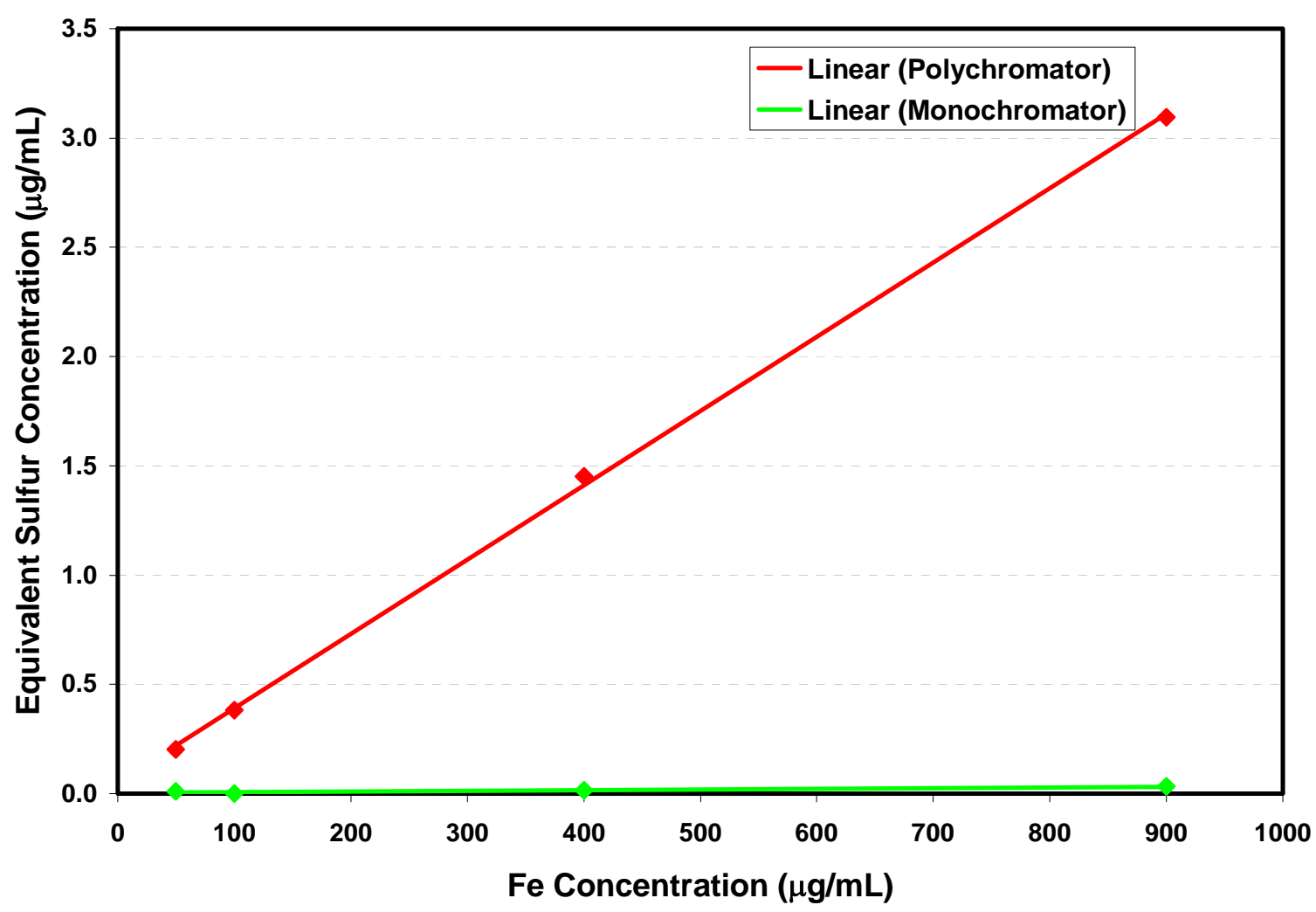

Figure 1. Iron spectral interference on sulfur concentration

\section{Conclusions \& Path Forward}

The monochromator $181.97 \mathrm{~nm}$ atomic emission line is superior for both examined figures of merit, LOD and spectral interference minimization. This spectrometer has a 5-fold better detection limit and requires only minimal overlap corrections ( 5\%), making it the line of choice for sulfur analysis in radioactive sludge. As time permits, future studies will be conducted on the final sulfur emission line at $180.676 \mathrm{~nm}$. This wavelength may have negligible spectral overlaps from concomitant matrix elements, eliminating the need for any spectral interference corrections. The poor signal to noise response for the sulfur polychromator channel will also be examined to see if the difference between the two spectrometers at the same sulfur line is real or an equipment malfunction in the polychromator. 
Table 3. Digested Radioactive Sludge Sulfur Concentrations ( $\mu \mathrm{g} / \mathrm{ml})$

\begin{tabular}{|c|c|c|c|c|c|c|c|}
\hline Customer ID & $\begin{array}{c}\text { S Mono } 181.978 \\
\text { Uncorrected } \\
\end{array}$ & $\begin{array}{c}\text { S Mono } 181.978 \\
\text { Corrected } \\
\end{array}$ & $\begin{array}{c}\% \\
\text { Correction } \\
\end{array}$ & $\begin{array}{c}\text { S Poly } 181.978 \\
\text { Uncorrected }\end{array}$ & $\begin{array}{c}\text { S Poly } 181.978 \\
\text { Corrected } \\
\end{array}$ & $\begin{array}{c}\% \\
\text { Correction } \\
\end{array}$ & $\begin{array}{l}\% \text { Difference } \\
\text { Mon vs. Poly }\end{array}$ \\
\hline \multicolumn{8}{|l|}{ Sludge Batch 2} \\
\hline AR-1-T40-Qual-1 & 3.956 & 3.774 & 4.8 & 6.746 & 3.492 & 93 & 7 \\
\hline AR-1-T40-Qual-2 & 3.908 & 3.729 & 4.8 & 6.550 & 3.343 & 96 & 10 \\
\hline AR-1-T40-Qual-3 & 3.584 & 3.416 & 4.9 & 7.424 & 4.436 & 67 & 30 \\
\hline AR-1-T40-Qual-4 & 3.763 & 3.586 & 4.9 & 6.449 & 3.276 & 97 & 9 \\
\hline \multicolumn{8}{|l|}{ Sludge Batch3 } \\
\hline$\overline{\text { AR-1-T51-Qual-1 }}$ & 6.973 & 6.659 & 4.7 & 10.438 & 6.059 & 72 & 9 \\
\hline AR-1-T51-Qual-2 & 7.657 & 7.320 & 4.6 & 11.095 & 6.382 & 74 & 13 \\
\hline AR-1-T51-Qual-3 & 7.737 & 7.400 & 4.6 & 11.228 & 6.535 & 72 & 12 \\
\hline AR-1-T51-Qual-4 & 7.472 & 7.140 & 4.7 & 10.993 & 6.337 & 73 & 11 \\
\hline Average: & & & 4.8 & & & 81 & 13 \\
\hline
\end{tabular}


Table 4. Sludge Batch 2 Sulfur Concentrations ( $\mu \mathrm{g} / \mathrm{mL})$ for both ICP-ES Emission Lines.

\begin{tabular}{|c|c|c|c|c|c|c|c|c|c|c|c|c|c|c|}
\hline \multirow[b]{2}{*}{ LIMS \# } & \multirow[b]{2}{*}{ Customer ID } & \multirow{2}{*}{$\begin{array}{r}\text { S Mono } 181.978 \\
\text { Uncorrected } \\
\end{array}$} & \multicolumn{11}{|c|}{ Spectral Interference Correction on Sulfur } & \multirow{2}{*}{$\begin{array}{c}\text { S Mono } 181.978 \\
\text { Corrected } \\
\end{array}$} \\
\hline & & & Al & $\mathbf{C a}$ & $\mathrm{Fe}$ & $\mathrm{Mg}$ & $\mathrm{Mn}$ & $\mathrm{Na}$ & $\mathrm{Ni}$ & $\mathbf{P}$ & Si & $\mathrm{Sr}$ & $\mathbf{U}$ & \\
\hline 205573 & AR1-BLK-1-T40 & 0.051 & 0.000 & 0.000 & 0.000 & 0.000 & 0.000 & 0.000 & 0.000 & 0.000 & 0.000 & 0.000 & 0.000 & 0.051 \\
\hline 205574 & S-1 & 0.020 & 0.001 & 0.000 & 0.000 & 0.000 & 0.000 & 0.002 & 0.000 & 0.000 & 0.000 & 0.000 & 0.000 & $<0.02$ \\
\hline 205575 & AR-1-T40-Qual-1 & 3.956 & 0.027 & 0.003 & 0.018 & 0.005 & 0.089 & 0.004 & 0.003 & 0.000 & 0.000 & 0.001 & 0.032 & 3.774 \\
\hline 205576 & AR-1-ARG-1-T40 & 1.034 & 0.018 & 0.002 & 0.012 & 0.002 & 0.065 & 0.007 & 0.003 & 0.000 & 0.000 & 0.001 & 0.000 & 0.925 \\
\hline 205577 & AR1-T40-Qual-2 & 3.908 & 0.027 & 0.003 & 0.017 & 0.005 & 0.088 & 0.004 & 0.003 & 0.000 & 0.000 & 0.001 & 0.031 & 3.729 \\
\hline 205578 & S-2 & 0.043 & 0.001 & 0.000 & 0.000 & 0.000 & 0.000 & 0.002 & 0.000 & 0.000 & 0.000 & 0.000 & 0.000 & 0.040 \\
\hline 205579 & AR-1-ARG-T40 & 1.032 & 0.018 & 0.002 & 0.012 & 0.002 & 0.064 & 0.007 & 0.003 & 0.000 & 0.000 & 0.001 & 0.000 & 0.923 \\
\hline 205580 & AR-1-T40-Qual-3 & 3.584 & 0.026 & 0.003 & 0.016 & 0.005 & 0.082 & 0.004 & 0.003 & 0.000 & 0.000 & 0.001 & 0.029 & 3.416 \\
\hline 205581 & AR-1-ARG-3T40 & 1.020 & 0.018 & 0.002 & 0.011 & 0.002 & 0.063 & 0.007 & 0.003 & 0.000 & 0.000 & 0.001 & 0.000 & 0.914 \\
\hline 205582 & AR-1-T40-Qual-4 & 3.763 & 0.027 & 0.003 & 0.017 & 0.005 & 0.087 & 0.004 & 0.003 & 0.000 & 0.000 & 0.001 & 0.030 & 3.586 \\
\hline 205583 & S-3 & 0.025 & 0.001 & 0.000 & 0.000 & 0.000 & 0.000 & 0.002 & 0.000 & 0.000 & 0.000 & 0.000 & 0.000 & 0.022 \\
\hline
\end{tabular}

\begin{tabular}{|c|c|c|c|c|c|c|c|c|c|c|c|c|c|c|}
\hline \multirow[b]{2}{*}{ LIMS \# } & \multirow[b]{2}{*}{ Customer ID } & \multirow{2}{*}{$\begin{array}{c}\text { S Poly } 181.978 \\
\text { Uncorrected }\end{array}$} & \multicolumn{11}{|c|}{ Spectral Interference Correction on Sulfur } & \multirow{2}{*}{$\begin{array}{c}\text { S Poly } 181.978 \\
\text { Corrected }\end{array}$} \\
\hline & & & Al & $\mathrm{Ca}$ & $\mathrm{Fe}$ & Mg & Mn & $\mathrm{Na}$ & $\mathrm{Ni}$ & $\mathbf{P}$ & Si & $\mathrm{Sr}$ & $\mathbf{U}$ & \\
\hline 205573 & AR1-BLK-1-T40 & 0.014 & 0.000 & 0.000 & 0.000 & 0.000 & 0.000 & 0.000 & 0.000 & 0.000 & 0.000 & 0.000 & 0.000 & $<0.1$ \\
\hline 205574 & S-1 & 0.127 & 0.005 & 0.000 & 0.015 & 0.000 & 0.000 & 0.008 & 0.000 & 0.000 & 0.048 & 0.000 & 0.000 & $<0.1$ \\
\hline 205575 & AR-1-T40-Qual-1 & 6.746 & 0.124 & 0.043 & 1.617 & 0.023 & 1.181 & 0.014 & 0.010 & 0.000 & 0.013 & 0.008 & 0.220 & 3.492 \\
\hline 205576 & AR-1-ARG-1-T40 & 3.229 & 0.082 & 0.031 & 1.064 & 0.010 & 0.854 & 0.026 & 0.011 & 0.000 & 0.002 & 0.006 & 0.000 & 1.144 \\
\hline 205577 & AR1-T40-Qual-2 & 6.550 & 0.122 & 0.042 & 1.597 & 0.023 & 1.168 & 0.014 & 0.010 & 0.000 & 0.012 & 0.008 & 0.212 & 3.343 \\
\hline 205578 & $\mathrm{~S}-2$ & 0.160 & 0.004 & 0.000 & 0.015 & 0.000 & 0.000 & 0.008 & 0.000 & 0.000 & 0.048 & 0.000 & 0.000 & $<0.1$ \\
\hline 205579 & AR-1-ARG-T40 & 2.947 & 0.082 & 0.030 & 1.058 & 0.010 & 0.849 & 0.026 & 0.011 & 0.000 & 0.002 & 0.006 & 0.000 & 0.874 \\
\hline 205580 & AR-1-T40-Qual-3 & 7.424 & 0.118 & 0.040 & 1.482 & 0.021 & 1.084 & 0.014 & 0.009 & 0.000 & 0.012 & 0.008 & 0.201 & 4.436 \\
\hline 205581 & AR-1-ARG-3T40 & 2.994 & 0.081 & 0.029 & 1.027 & 0.010 & 0.830 & 0.025 & 0.010 & 0.000 & 0.002 & 0.005 & 0.000 & 0.975 \\
\hline 205582 & AR-1-T40-Qual-4 & 6.449 & 0.123 & 0.041 & 1.579 & 0.022 & 1.153 & 0.014 & 0.010 & 0.000 & 0.012 & 0.008 & 0.212 & 3.276 \\
\hline 205583 & S-3 & 0.089 & 0.004 & 0.000 & 0.015 & 0.000 & 0.000 & 0.008 & 0.000 & 0.000 & 0.048 & 0.000 & 0.000 & $<0.1$ \\
\hline
\end{tabular}


Table 5. Sludge Batch 3 Sulfur Concentrations ( $\mu \mathrm{g} / \mathrm{mL})$ for both ICP-ES Emission Lines.

\begin{tabular}{|c|c|c|c|c|c|c|c|c|c|c|c|c|c|c|}
\hline \multirow[b]{2}{*}{ LIMS \# } & \multirow[b]{2}{*}{ Customer ID } & \multirow{2}{*}{$\begin{array}{c}\text { S Mono } 181.978 \\
\text { Uncorrected }\end{array}$} & \multicolumn{11}{|c|}{ Spectral Interference Correction on Sulfur } & \multirow{2}{*}{$\begin{array}{c}\text { S Mono } 181.978 \\
\text { Corrected }\end{array}$} \\
\hline & & & Al & $\mathrm{Ca}$ & $\mathrm{Fe}$ & $\mathrm{Mg}$ & $\mathrm{Mn}$ & $\mathrm{Na}$ & $\mathrm{Ni}$ & $\mathbf{P}$ & $\mathrm{Si}$ & $\mathrm{Sr}$ & $\mathbf{U}$ & \\
\hline 205708 & AR1-BLK-1-T51 & 0.075 & 0.000 & 0.000 & 0.000 & 0.000 & 0.000 & 0.000 & 0.000 & 0.000 & 0.000 & 0.000 & 0.000 & 0.075 \\
\hline 205709 & S-1 & 1.032 & 0.020 & 0.002 & 0.011 & 0.002 & 0.065 & 0.007 & 0.003 & 0.000 & 0.000 & 0.001 & 0.000 & 0.921 \\
\hline 205710 & AR-1-T51-Qual-1 & 6.973 & 0.048 & 0.002 & 0.016 & 0.006 & 0.175 & 0.009 & 0.003 & 0.000 & 0.000 & 0.001 & 0.054 & 6.659 \\
\hline 205711 & AR-1-ARG-1-T51 & 0.922 & 0.018 & 0.002 & 0.010 & 0.002 & 0.060 & 0.006 & 0.003 & 0.000 & 0.000 & 0.001 & 0.000 & 0.820 \\
\hline $\begin{array}{l}205712 \\
\text { NOT IN }\end{array}$ & $\begin{array}{c}\text { AR1-T51-Qual-2 } \\
\text { S-2 }\end{array}$ & 7.657 & 0.052 & 0.003 & 0.017 & 0.007 & 0.188 & 0.010 & 0.004 & 0.000 & 0.000 & 0.001 & 0.057 & 7.320 \\
\hline 205713 & AR-1-ARG-T51 & 0.843 & 0.016 & 0.002 & 0.009 & 0.002 & 0.054 & 0.006 & 0.002 & 0.000 & 0.000 & 0.000 & 0.000 & 0.751 \\
\hline 205714 & AR-1-T51-Qual-3 & 7.737 & 0.051 & 0.003 & 0.017 & 0.007 & 0.187 & 0.010 & 0.004 & 0.000 & 0.000 & 0.001 & 0.058 & 7.400 \\
\hline 205715 & AR-1-ARG-3T51 & 0.810 & 0.016 & 0.002 & 0.009 & 0.002 & 0.054 & 0.006 & 0.002 & 0.000 & 0.000 & 0.000 & 0.000 & 0.719 \\
\hline 205716 & AR-1-T51-Qual-4 & 7.472 & 0.051 & 0.003 & 0.017 & 0.007 & 0.186 & 0.010 & 0.003 & 0.000 & 0.000 & 0.001 & 0.056 & 7.140 \\
\hline NOT IN & S-3 & & & & & & & & & & & & & \\
\hline
\end{tabular}

\begin{tabular}{|c|c|c|c|c|c|c|c|c|c|c|c|c|c|c|}
\hline \multirow[b]{2}{*}{ LIMS \# } & \multirow[b]{2}{*}{ Customer ID } & \multirow{2}{*}{$\begin{array}{c}\text { S Poly } 181.978 \\
\text { Uncorrected }\end{array}$} & \multicolumn{11}{|c|}{ Spectral Interference Correction on Sulfur } & \multirow{2}{*}{$\begin{array}{c}\text { S Poly } 181.978 \\
\text { Corrected }\end{array}$} \\
\hline & & & Al & $\mathrm{Ca}$ & $\mathrm{Fe}$ & Mg & Mn & $\mathrm{Na}$ & $\mathrm{Ni}$ & $\mathbf{P}$ & Si & $\mathrm{Sr}$ & $\mathbf{U}$ & \\
\hline 205708 & "AR1-BLK-1-T51 & 0.090 & 0.000 & 0.000 & 0.000 & 0.000 & 0.000 & 0.000 & 0.000 & 0.000 & 0.000 & 0.000 & 0.000 & 0.089 \\
\hline 205709 & S-1 & 3.044 & 0.082 & 0.030 & 1.031 & 0.010 & 0.868 & 0.026 & 0.010 & 0.000 & 0.000 & 0.006 & 0.000 & 0.980 \\
\hline 205710 & AR-1-T51-Qual-1 & 10.438 & 0.197 & 0.036 & 1.433 & 0.026 & 2.345 & 0.036 & 0.011 & 0.000 & 0.015 & 0.007 & 0.273 & 6.059 \\
\hline 205711 & AR-1-ARG-1-T51 & 2.671 & 0.075 & 0.028 & 0.952 & 0.009 & 0.802 & 0.024 & 0.010 & 0.000 & 0.025 & 0.005 & 0.001 & 0.741 \\
\hline 205712 & AR1-T51-Qual-2 & 11.095 & 0.214 & 0.038 & 1.545 & 0.028 & 2.524 & 0.039 & 0.012 & 0.000 & 0.017 & 0.008 & 0.288 & 6.382 \\
\hline NOT IN & $\mathrm{S}-2$ & & & & & & & & & & & & & \\
\hline 205713 & AR-1-ARG-T51 & 2.429 & 0.068 & 0.025 & 0.861 & 0.008 & 0.724 & 0.022 & 0.009 & 0.000 & 0.015 & 0.005 & 0.000 & 0.692 \\
\hline 205714 & AR-1-T51-Qual-3 & 11.228 & 0.213 & 0.038 & 1.535 & 0.028 & 2.510 & 0.039 & 0.012 & 0.000 & 0.015 & 0.008 & 0.294 & 6.535 \\
\hline 205715 & AR-1-ARG-3T51 & 2.425 & 0.067 & 0.025 & 0.860 & 0.008 & 0.722 & 0.022 & 0.009 & 0.000 & 0.019 & 0.005 & 0.000 & 0.689 \\
\hline 205716 & AR-1-T51-Qual-4 & 10.993 & 0.211 & 0.038 & 1.537 & 0.028 & 2.488 & 0.038 & 0.012 & 0.000 & 0.014 & 0.007 & 0.284 & 6.337 \\
\hline NOT IN & S-3 & & & & & & & & & & & & & \\
\hline
\end{tabular}

